\title{
In vivo evaluation of therapeutic potential of fluoride varnishes
}

\section{Avaliação in vivo do potencial terapêutico de vernizes fluoretados}

\begin{abstract}
Purpose: To perform an in vivo evaluation of the therapeutic effect of two fluoride varnishes on the remineralization of active white spot lesions (WSLs).

Methods: Children aged 7 to 10 years old $(n=20)$ with 56 active WSLs in the anterior permanent teeth were submitted to four weekly applications of fluoride products: $G 1$ - Fluorphat ${ }^{\circledR}(n=28)$ or $G 2$ - Duraphat ${ }^{\circledast}(n=28)$. WSLs were evaluated with regard to diameter and activity. Data were analyzed by descriptive and inferential statistics (Student's $\dagger$ and chi-square tests), with the significance level set to $5 \%$.

Results: At the end of the study, G1 had nine active and 19 inactive WSLs and G2 had seven and 21 inactive WSLs. No difference in mean WSL size was found between G1 (4.37 $\mathrm{mm})$ and $\mathrm{G} 2(4.76 \mathrm{~mm})(P>0.05)$. In the intragroup analysis, significant differences were found between the initial and final WSL size in both G1 (from $4.37 \mathrm{~mm}$ to $2.97 \mathrm{~mm}$ ) and $\mathrm{G} 2(4.76 \mathrm{~mm}$ to $3.78 \mathrm{~mm})$.

Conclusion: The two products tested demonstrated similar clinical efficacy regarding the remineralization of active WSLs after four weeks of fluoride therapy.
\end{abstract}

Key words: Dental caries; tooth remineralization; fluorides

\section{Resumo}

Objetivo: Realizar uma avaliação in vivo do efeito terapêutico de dois vernizes fluoretados sobre a remineralização de lesões brancas ativas (MBAs).

Metodologia: Crianças entre 7 e 10 anos de idade $(n=20)$ com 56 MBAs nos dentes anteriores permanentes foram submetidos a quarto aplicações semanais de produtos fluoretados: G1 - Fluorphat ${ }^{\circledR}(n=28)$ ou $G 2$ - Duraphat $^{\circledR}(n=28)$. MBAs foram avaliados em relação ao diâmetro e atividade. Os dados foram analisados por estatísticas descritiva e inferencial (teste $\dagger$ de Student e teste qui-quadrado), com nível de significância de 5\%.

Resultados: No final do estudo, G1 tinha 9 MBAs ativas e 19 inativas e G2 tinha 7 MBAs ativas e 21 inativas. Nenhuma diferença em tamanho médio de MBA foi encontrada entre G1 $(4,37 \mathrm{~mm})$ e $G 2(4,76 \mathrm{~mm})(P>0,05)$. Na análise intragrupo, diferenças significantes foram encontradas entre os tamanhos inicial e final de MBA em ambos os grupos Gl (de 4,37 mm a 2,97 mm) e G2 (4,76 mm a 3,78 mm).

Conclusão: Os dois produtos testados demonstraram eficácia clínica similar para a remineralização de MBAs ativas após quatro semanas de terapia com flúor.

Palavras-chave: Cárie dental; remineralização dental; fluoretos

\author{
Rúbia Menêses da Silva a \\ Jainara Maria Soares Ferreira b \\ Cely Dayana Barros da Silva a \\ Luciana de Barros Correia Fontes a \\ Ana Flávia Granville-Garcia a \\ Valdenice Aparecida de Menezes ${ }^{c}$
}

- School of Dentistry, State University of Paraiba, João Pessoa, PB, Brazil

b School of Dentistry, University Center of João Pessoa (UNIPÊ), João Pessoa, PB, Brazil

c School of Dentistry, University of Pernambuco (UPE), Camaragibe, PE, Brazil

\author{
Correspondence: \\ Jainara Maria Soares Ferreira \\ Av. Júlia Freire, 1200/202 \\ Expedicionários \\ Joao Pessoa, PB - Brasil \\ 58040-040 \\ E-mail: jainara.s@ig.com.br
}

Received: April 7, 2012

Accepted: September 14, 2012

Conflict of Interests: The authors state that there are no financial and personal conflicts of interest that could have inappropriately influenced their work.

Copyright: (C) 2012 Silva et al.; licensee EDIPUCRS. This is an Open Access article distributed under the terms of the Creative Commons AttributionNoncommercial-No Derivative Works 3.0 Unported License. 


\section{Introduction}

Dental caries are one of the most prevalent oral health conditions worldwide (1). The multifactor nature of this disease, classically described by Paul Keyes in the 1960s, is related to an imbalance between the dental structure and oral environment. Microbiota, diet and host characteristics are the etiological factors of the onset and progression of caries. The modern conception of dental cares also considers social and behavioral factors (2).

White spots are the first visual clinical presentation of dental caries and are characterized by the de-mineralization of the subsurface of the enamel, with an increase in porosity due to the removal of minerals from the deep tissue to the outer surface. White spots are classified as either active (rough and opaque) or inactive (smooth and shiny) (3).

Due to changes in the conception of the dynamics of dental caries, the current philosophy in dentistry is directed toward early diagnosis and the use of noninvasive treatment to stop or reverse incipient carious lesions with the use of fluoride (4). Toothpastes, mouthwashes, gels and varnishes are the most common forms of the topical application of fluoride (5). Fluoride varnishes are described as the most convenient form of the professional use of topical fluoride for preschoolers, as these substances are easy to apply and are well tolerated by the patient $(6,7)$. Such varnishes have a greater concentration [around 22,000 parts per million (ppm) of fluoride]. The slow-release mechanism forms calcium fluoride compounds on the surface of the tooth and makes fluoride available to the saliva as well $(8,9)$. The varnish is not affected by moisture and remains adhered to the enamel for a significant period of time without requiring the cooperation of the patient. These characteristics indicate that fluoride varnishes may be incorporated into clinical routines and public health practices $(5,8)$. A number of studies have demonstrated that such varnishes are capable or remineralizing incipient carious lesions and preventing caries when used in conjunction with other preventive measures, such as the control dental biofilm (plaque) and $\operatorname{diet}(10-13)$.

Considering the diversity of commercial brands and the different prices of fluoride varnishes, it is fundamental for dentists to know whether national and imported products have the same effectiveness regarding remineralization and impeding the activity of white spots through an analysis of the cost-benefit ratio. Thus, the aim of the present study was to perform an in vivo evaluation of the effects of the fluoride varnishes Duraphat ${ }^{\mathbb{B}}$ (imported) and Fluorphat ${ }^{\mathbb{R}}$ (national) on the remineralization of active white spots in children aged seven to 10 years at a public school in the city of Campina Grande, state of Paraíba, Brazil.

\section{Methodology}

This study was approved by the Ethics Committee of the Center for Biological and Health Sciences of the Universidade Estadual da Paraíba, in João Pessoa, PB, Brazil
(Protocol 0345.0.133.000-11). Parents/guardians authorized the participation of the children by signing a statement of informed consent in compliance with Resolution $n^{\circ}$ 196/96 of the Brazilian National Health Board. This study received no financial support.

A longitudinal clinical trial was carried out in which each individual served as his/her own control. Children aged seven to 10 years enrolled in the public school system in the city of Campina Grande participated in the study. The inclusion criterion was incipient active carious lesions (rough, opaque white spots) on the anterior teeth. The exclusion criteria were syndromes, dental development abnormalities, the use of an orthodontic appliance, medications that altered salivary flow/composition or antibiotics in the month prior to the exam.

The sample size was based on the study of Ferreira et al. (15), who compared two groups of varnishes (national and imported) using a similar methodology, with 22 and 23 cases in each group, respectively. The sample was increased by $30 \%$ to compensate for possible losses, leading to two groups of 30 patients each. Twenty-two of 60 children with active white spots initiated the study. Two patients with four white spot lesions dropped out. Thus, 20 children with 56 active white spots effectively participated in the study.

The clinical exam and application of the fluoride varnish were performed under natural light in an open environment at the school. A form was drafted for the identification of the child and recording of the data. The data were collected by a single, duly calibrated examiner (Kappa $=1.0$ for dimension and activity) with the assistance of a previously trained annotator. The clinical exam involved the assessment of dimensional alterations and activity (texture and luminosity).

Prior to the clinical exam, the simplified Oral Hygiene Index (OHI-S) proposed by Greene and Vermillion (14) was determined using a basic fuchsine solution (Replak ${ }^{\circledR}$, Dentsply, Petrópolis, RJ, Brazil) on the vestibular faces of the permanent first molars and right central incisor in the upper arch and the lingual faces of the permanent first molars and vestibular face of the left central incisor in the lower arch. Plaque buildup was scored as follows: $0=$ surface free of biofilm; $1=1 / 3$ of surface covered with biofilm; $2=2 / 3$ of surface covered with biofilm; $3=$ entire surface covered with biofilm.

Supervised tooth brushing was performed in every session following the determination of the OHI-S and prior to the topical application of fluoride. Each child received a children's toothbrush (Colgate Clássico Infantil ${ }^{\circledR}$, Colgate-Palmolive, São Bernardo do Campo, SP, Brazil) and fluoride dentifrice (1100 ppm of fluoride) (Tandy ${ }^{\circledR}$, Colgate-Palmolive, São Bernardo do Campo, SP, Brazil). Standardized instructions were given to ensure the same oral hygiene conditions for all participants.

The white spots were then measured by the largest mesiodistal and cervico-incisal diameter in $\mathrm{mm}$ with the aid of a WHO periodontal probe (Trinity ${ }^{\mathbb{B}}$, São Paulo, SP, Brazil) and mean measurements were recorded. Dimensional alterations, 
texture (roughness or smoothness) and luminosity (opacity or shine) were also evaluated and the spots were classified as either active (rough and opaque) or inactive (smooth and shiny) (15).

For the application of the fluoride varnishes, the children were randomly divided into two groups: Group 1 (G1) received Fluorphat ${ }^{\circledR}(5 \% \mathrm{NaF}=2.26 \% \mathrm{~F}$, Inodon, Porto Alegre, Brazil; $n=28)$ and Group $2(\mathrm{G} 2)$ received Duraphat ${ }^{\circledR}$ $(5 \% \mathrm{NaF}=2.26 \% \mathrm{~F}$, Colgate-Palmolive, Germany; $\mathrm{n}=28)$.

The following clinical sequence was obeyed in both groups: 1) supervised brushing; 2) drying with gauze; 3) application of fluoride varnish on active white spots with the aid of a brush (FGM, Joinvile, Brazil); 4) five-minute wait for the evaporation of the solvent; 5) removal of excess with cotton ball; and 6) instructions to not brush the teeth and to use a diet of liquids or pasty foods for 12 hours following the application of the product. These clinical procedures were performed once a week for four weeks $(16,17)$. On the fifth week, the white spots were evaluated with regard to dimension and activity.

Data were analyzed by descriptive and inferential statistics (Pearson's chi-square test and Student's $t$-test), with the level of significance set to $5 \%(P<0.05)$.

\section{Results}

Twenty children (10 boys and 10 girls) participated in the present study (mean age \pm standard deviation: $8.55 \pm 0.94$ years). The sample was composed of 56 incipient carious lesions on the vestibular surface of the permanent anterior teeth. All white spots were active (rough and opaque) at the beginning of the study.

A statistically significant difference was found in the mean OHI-S between the initial $(1.46 \pm 0.55)$ and final (1.01 \pm 0.52$)$ evaluations $(P<0.05$; paired Student's $t$-test $)$, demonstrating an improvement in the children's oral hygiene (Fig. 1). A statistically significant difference was found in the numerical dimensions of the white spots between the initial $(4.56 \pm 2.14)$ and final $(3.38 \pm 2.35)$ evaluations $(P<0.05$; paired Student's $t$-test), demonstrating a $25.8 \%$ reduction in size.

Figure 2 displays the mean white spot dimensions in the first and fifth week of the study $(4.37 \pm 2.10$ and $2.97 \pm 2.21$ in $\mathrm{G} 1$, respectively; $4.76 \pm 2.19$ and $3.78 \pm 2.46$ in $\mathrm{G} 2$, respectively), with statistically significant reductions in both groups $(P<0.05$, paired Student's $t$-test). In the intergroup analysis, no statistically significant differences were found between the fluoride varnishes tested $(P>0.05$, Student's $t$-test).

Regarding white spot activity on the five-week evaluation, nine spots remained active and 19 were inactive in G1 and seven spots remained active and 21 were inactive in G2, with no statistically significant differences between groups ( $P>0.05$, Pearson's chi-square test). Among the total number of 56 initial white spots, $16(28.4 \%)$ remained active and $40(71.4 \%)$ had become inactive at the end of the study (Table 1).

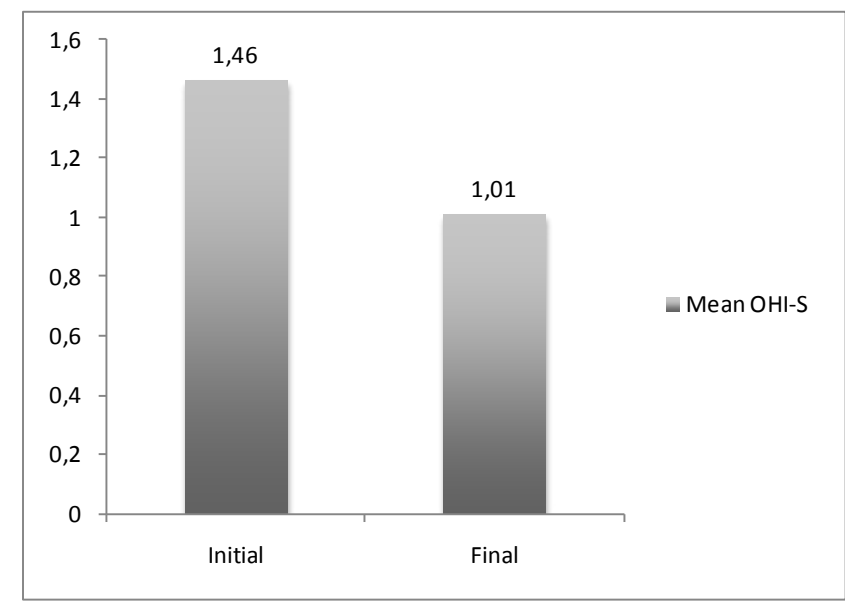

Fig. 1. Distribution of mean $\mathrm{OH}-\mathrm{S}$ on initial and final evaluations. Campina Grande, PB, Brazil, 2011 ( $P<0.05$, Student's † test).

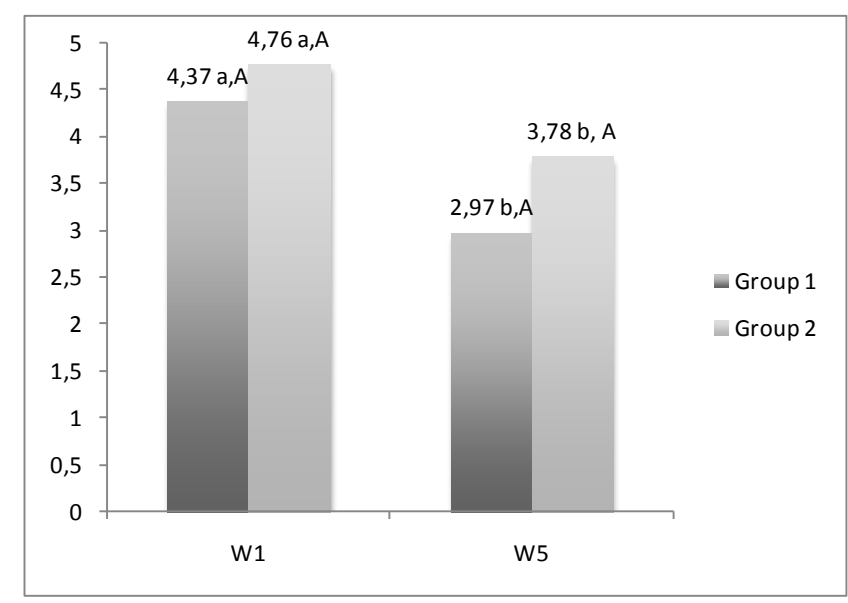

Fig. 2. Distribution of mean white spot dimension according to fluoride products. Campina Grande, PB, Brazil, 2011 . Means followed by different lowercase letters indicate statistically significant difference between initial and final evaluations $(P<0.05$, paired Student's $t$-test). Means followed by uppercase letters indicate non-significant difference between groups on the same evaluation ( $P>0.05$, Student's $t$-test).

Table 1. Clinical evaluation of activity of white spots submitted to fluoride varnishes. Campina Grande, PB, Brazil, 2011

\begin{tabular}{cccc}
\hline \multirow{2}{*}{ Groups } & \multicolumn{2}{c}{ Activity } & \multirow{2}{*}{ Total } \\
\cline { 2 - 3 } & Active & Inactive & \\
\cline { 2 - 4 } & $\mathrm{n}(\%)$ & $\mathrm{n}(\%)$ & $\mathrm{N}(\%)$ \\
\hline G1 & $09(32,1)$ & $19(67,9)$ & $28(100,0)$ \\
G2 & $07(25,0)$ & $21(75,0)$ & $28(100,0)$ \\
Total & $16(28,6)$ & $40(71,4)$ & $56(100,0)$ \\
\hline
\end{tabular}

( $P>0,05$, Pearson's Chi-square test). 


\section{Discussion}

Both products tested demonstrated efficacy in the remineralization of teeth with white spots following four weekly applications. A total of $71.4 \%$ of the spots became inactive and there was a significant reduction of $25.8 \%$ in mean size for the overall sample. These results corroborate findings described in the literature regarding the remineralization power of fluoride varnishes used to treat caries $(10-13,16)$.

A reduction in the mean OHI-S score occurred throughout the study. It is likely that the positive effect of the fluoride varnishes was assisted by the improvement in oral hygiene on the part of the participants. Indeed, previous studies state that one cannot dissociate the effect of fluoride varnishes from the effect of proper brushing $(8,17,18)$.

Both groups [G1 (Fluorphat $\left.{ }^{\circledR}\right)$ and G2 (Duraphat $\left.{ }^{\circledR}\right)$ ] demonstrated similar efficacy regarding changes in white spot activity and size. These results differ from those reported in an in vitro study carried out by Mass et al. (18), who assessed the fluoride varnishes Duraphat ${ }^{\mathbb{R}}$, Bifluorid $12^{\circledR}$, Fluorphat ${ }^{\circledR}$, Biophat, ${ }^{\circledR}$ Fluorniz ${ }^{\circledR}$, Duofluorid XII ${ }^{\circledR}$ and Duraflur $^{\circledR}$ and concluded that only Duraflur ${ }^{\circledR}$ and Duofluorid XII (produced in Brazil) achieved similar effectiveness to the imported varnishes Duraphat ${ }^{\circledR}$ and Bifluorid $12^{\circledR}$. Further comparative clinical and laboratory trials are needed to determine the efficacy of different fluoride varnishes, as the literature on the use of Brazilian products remains scarce.

In terms of the cost-benefit ratio, the results of the present study encourage the use of the Brazilian product, as both products tested had a similar clinical performance and the imported varnish can cost as much as 14-fold more than the national product. This finding is of considerable importance in the public health realm, where administrators often have to share and allocate scarce resources by establishing priorities.

A satisfactory clinical performance was observed over four weeks of applications with both products on children. This result corroborates findings described in the literature $(16,20)$. The occurrence of inactive white spots and the significant reduction in the size of these spots following weekly applications of the fluoride varnishes demonstrates the possibility of stopping or reversing incipient carious lesions with no need for invasive treatment. This result is also in agreement with findings reported in previous studies $(10,13,16,20-23)$.

Under the conditions tested in the present study, no differences were found in the performance of the fluoride varnishes analyzed with regard to the remineralization of teeth with incipient carious lesions, as both products proved effective in the treatment of white spots. These findings may be important to public dental services in the planning of oral health programs, especially those directed at children.

\section{Conclusions}

Both products had similar in vivo results, suggesting the efficacy of the fluoride varnishes tested regarding the remineralization of active white spots after four weeks of treatment.
References

. Habibian M, Roberts G, Lawson M, Stevenson R, Harris S. Dietary habits and dental health over the first 18 months of life. Community Dent Oral Epidemiol 2001 ;29:239-46.

2. Fejerskov $\bigcirc$. Changing paradigms in concepts on dental caries: consequences for oral health care. Caries Res 2004;8:182-91.

3. Zero DT. Dental caries process. Dent Clin North Amer 1999;43:635-63.

4. Stahl J, Zandona AF. Rationale and protocol for the treatment of non-cavitated smooth surface carious lesions. Gen Dent 2007;55:105-11.

5. American Dental Association Council on Scientific Affairs. Professionally applied topical fluoride: Evidence-based clinical recommendations. J Am Dent Soc 2006;137:1 151-9.

6. National Institutes of Health (NIH). Consensus Development Conference on Diagnosis and Management of Dental Caries Throughout Life. Conference Papers. J Dent Educ $2001 ; 65: 935-1179$.

7. Beltran-Aguilar ED, Goldstein JW, Lockwood SA. Fluoride varnishes. A review of their clinical use, cariostatic mechanism, efficacy and safety. J Am Dent Assoc 2000;131:589-96.

8. Marinho VC, Higgins JP. Topical fluoride (toothpastes, mouthrinses, gelsor varnishes) for preventing dental caries in children and adolescents. Cochrane Database Syst Rev 2008;20:3-7.

9. Petersson LG, Twelman S, Dahlgren H, Norlund A, Holm AK, Nordenram G, et al. Professional fluoride varnish treatment for caries control: a systematic review of clinical trials. Acta Odontol Scand 2004;62:170-6.

10. Du M, Cheng N, Tai B, Jiang H, Li J, Bian Z. Randomized controlled trial on fluoride varnish application for treatment of white spot lesion after fixed orthodontic treatment. Clin Oral Investig 2011 [Epub ahead of print. DOI: 10.1007/s00784-011-0520-4].

1 1. Seppä L. Studies of fluoride varnishes in Finland. Proc Finn Dent Soc Helsinki 1991;87:541-7.

12. Slade GD, Bailie RS, Roberts-Thomson K, Leach AJ, Raye I, Endean C, et al. Effect of health promotion and fluoride varnish on dental caries among Australian Aboriginal children: results from a community-randomized controlled trial. Community Dent Oral Epidemiol $2011 ; 39: 29-43$ 
13. Weintraub JA, Ramos-Gomez F, Jue B, Shain S, Hoover Cl, Featherstone JD, et al. Fluoride varnish efficacy in preventing early childhood caries. J Dent Res 2006;85:172-6.

14. Greene JC, Vermillion JR. The simplified oral hygiene index. J. Am. Dent. Assoc 1964;64:25-31.

15. Nyvad B, Machiulskiene V, Baelum V. Reliability of a new caries diagnostic system differentiating between active and inactive caries lesions. Caries Res 1999;33:254-60.

16. Ferreira JMS, Aragão AKR, Rosa ADB, Sampaio FC, Menezes VA. Therapeutic effect of two fluoride varnishes on white spot lesions: a randomized clinical trial. Braz Oral Res $2009 ; 23: 446-51$.

17. Hayacibara ME, Paes Leme AF, Lima YBO, Gonçalves NCLAV, Queiroz CS, Gomes J et al. Alkali - soluble fluoride deposition on enamel after professional application of topical fluoride in vitro. J Appl Oral Sci 2004;12:8-21.

18. Sellos MC, Malta MCB, Ferreira JOR, Santos APP, Soviero VM. Avaliação clínica do efeito adicional do verniz fluoretado sobre a inativação de lesões iniciais de cárie em dentes decíduos. Ciênc Odontol Bras 2008;1 1:66-73.

19. Mass JRS, Faraco-Junior I M, Raupp SM, Hirata E, Delbem ACB. Estudo in vitro da atividade anticariogênica e formação de $\mathrm{CaF}_{2}$ de vernizes fluoretados comercializados no Brasil. Braz Oral Res 2004;18 Suppl:133.

20. Almeida MQ, Costa OXI, Ferreira JMS, Menezes VA, Leal RB, Sampaio FC. Therapeutic potential of Brazilian fluoride varnishes: An in vivo study. Braz Dent J 2011 ;22:193-7.

21. Ögaard B. Effects of fluoride on caries development and progression in vivo. J Dent Res 1990;69:813-19

22. Khattak MF, Conry JP, Ko CC. Comparison of three topical fluorides using computer imaging. J Clin Pediatr Dent 2005;30:139-44.

23. Ekstrand KR, Bakhshandeh A, Martignon S. Treatment of proximal superficial caries lesions on primary molar teeth with resin infiltration and fluoride varnish versus fluoride varnish only: efficacy after 1 year. Caries Res 2010;44:41-6. 